\title{
Transformasi Pseudogravitasi Data Anomali Magnetik untuk Melokalisir Sumber Rembesan Minyak di Daerah Cipari Kebupaten Cilacap
}

\author{
Sehah $^{1}$, Sukmaji Anom Raharjo ${ }^{1}$, Pujo Priyadi ${ }^{2}$ \\ ${ }^{1}$ Dosen Program Studi Fisika, Fakultas MIPA, Universitas Jenderal Soedirman, \\ Jalan dr.Suparno No.61 Purwokerto \\ ${ }^{2}$ Pranata Laboratorium Pendidikan (PLP) Laboratorium Fisika Dasar, Fakultas MIPA, \\ Universitas Jenderal Soedirman, Jalan dr.Suparno No.61 Purwokerto \\ E-mail: sehah.geophysics@gmail.com \\ Telp/HP: 0813-275-07517
}

\begin{abstract}
ABSTRAK
Transformasi pseudogravitasi terhadap data anomali magnetik telah dilakukan untuk melokalisir sumber rembesan minyak di Desa Cipari Kecamatan Cipari Kabupaten Cilacap. Daerah penelitian membentang pada posisi $108,757^{\circ}-108,776^{\circ}$ BT dan $7,423^{\circ}-7,438^{\circ} \mathrm{LS}$. Penerapan transformasi pseudogravitasi ini bertujuan untuk memperjelas lokasi target anomali bawah permukaan. Berdasarkan peta kontur pseudogravitasi dan informasi geologi daerah penelitian, maka dilakukan pemodelan terhadap data anomali magnetik lokal menggunakan Mag2DC for Windows. Berdasarkan hasil pemodelan diperoleh beberapa benda anomali bawah permukaan yang diinterpretasi sebagai batuan beku basaltik $(\chi=0,0051)$, perselingan pasir dan lempung dengan sisipan napal dari formasi Halang $(\chi=0,0014)$, breksi basaltik dari formasi Kumbang $(\chi=0,0035)$, perselingan batupasir dan batulempung dengan sisipan breksi dari formasi Halang $(\chi=0,0036)$, batulempung dari formasi Tapak $(\chi=0,0015)$, perselingan batupasir dan batulempung dengan sisipan napal dan breksi dari formasi Halang $(\chi=0,0030)$, serta perselingan batupasir dan batulempung dari formasi Halang $(\chi=0,0020)$. Fosil foraminifera plantonik sebagai sumber rembesan minyak diperkirakan berada di dalam batuan-batuan sedimen tersebut, dimana cairan minyak mengalir dari batuan-batuan tersebut menuju ke reservoir (source rock). Berdasarkan hasil interpretasi, reservoir terletak di atas batuan beku basaltik dengan posisi $108,762^{\circ} \mathrm{BT}$ dan $7,431^{\circ} \mathrm{LS}$ serta kedalaman 132,09 meter di bawah topografi.
\end{abstract}

Kata Kunci: Transformasi pseudogravitasi; anomali magnetik; rembesan minyak; Cipari 


\begin{abstract}
The pseudogravity transformation of magnetic anomalies data had been done to determine of the oil seepage location of in Village of Cipari District of Cipari Region of Cilacap. The boundary of the research area is $108.75675^{\circ}-108.77611^{\circ} \mathrm{E}$ and $7.42319^{\circ}-7.43761^{\circ} \mathrm{S}$. The implement of pseudogravity transformation aims to clarify location of subsurface anomali's target. Based on the pseudogravity contour map supported the local geological information, so that modeling is applied to the local magnetic anomaly data using Mag2DC for Windows software. Based on the modeling results then be obtaided some anomalies bodies interpreted as the basaltic igneous rock $(\chi=0.0051)$, the alternately of sand and clays and insert of marl from Halang Formation $(\chi=0.0014)$, the breccia from Kumbang Formation $(\chi=0.0035)$, the alternately of sandstones and claystone with insert of breccia from Halang Formation $(\chi=0.0036)$, the claystone from Tapak Formation $(\chi=0.0015)$, the alternately of sandstones and claystone with insert of marl and breccia from Halang Formation $(\chi=0.0030)$, and the alternately of sandstone and claystone from Halang Formation $(\chi=0.0020)$. The plantonic foraminifer fossils as resources of oil seepage are estimated in the sediments rocks, where the oil flows from those rocks into the reservoir (source rock). Based on the interpretation results, the reservoir lies at above the basaltic igneous rock with the approximate position is $108.762^{\circ} \mathrm{W}$ and $7.431^{\circ} \mathrm{S}$; and the depth is 132.09 meters under the average topographic.
\end{abstract}

Keywords: pseudogravity transformation; magnetic anomaly; oil seepage; Cipari

\section{Pendahuluan}

Survei Magnetik adalah salah satu survei Geofisika yang bertujuan untuk mengeksplorasi sumberdaya alam bawah permukaan. Prinsip survei magnetik adalah dengan memanfaatkan variasi suseptibilitas magnetik batuan bawah permukaan yang terukur di atas permukaan bumi sebagai instrumen untuk menginterpretasi struktur geologi bawah permukaan bumi. Struktur geologi atau batuan bawah permukaan yang umum menjadi target survei magnetik antara lain: patahan, reservoir panas bumi, kantong magma, mineral logam, source rock minyak bumi, dan lain-lain. Secara umum prosedur survei magnetik terdiri atas akuisisi data di 
lapangan, pengolahan data, pemodelan, dan interpretasi.

Cipari adalah salah satu wilayah di Kabupaten Cilacap. Secara geologis Cipari terletak di Cekungan Banyumas (Banyumas Basin) dan dilewati oleh salah satu patahan utama di Jawa Tengah, yaitu Patahan Besar Cilacap - Pamanukan - Lematang [1]. Daerah Cipari merupakan daerah yang kompleks dengan struktur cukup beragam. Selain itu daerah ini juga memiliki potensi cadangan minyak bumi yang ditandai dengan munculnya rembesan minyak, sehingga hal ini menjadi tantangan tersendiri bagi para pelaku kegiatan eksplorasi. Eksplorasi perlu dilakukan di daerah Cipari, salah satunya adalah menggunakan metode magnetik. Data hasil eksplorasi ini dapat digunakan sebagai acuan untuk melakukan eksplorasi lanjutan, sehingga jika dinyatakan prospek, maka dapat dilanjutkan dengan pengeboran.

Target dalam eksplorasi metode magnetik ini adalah source rock rembesan minyak bumi di daerah Cipari. Untuk memperoleh model anomali yang diinterpretasi sebagai source rock rembesan minyak, maka perlu dilakukan transformasi. Salah satu transformasi data anomali magnetik yang berfungsi untuk memperjelas lokasi benda anomali bawah permukaan yang menjadi target penelitian adalah transformasi pseudogravitasi [2]. Lokasi source rock menjadi mudah diinterpretasi karena lapisan dasarnya diperkirakan berupa batuan beku yang memiliki densitas besar untuk memerangkap atau menampung minyak bumi. Prinsip kerja transformasi pseudogravitasi menggunakan relasi Poisson, yang menyatakan bahwa potensial magnetik $V$ dan potensial gravitasi $U$ yang bersumber dari suatu rapat massa yang serba sama (uniform) maupun benda yang termagnetisasi secara uniform mempunyai hubungan [3]:

$$
V=-\frac{C_{m}}{\gamma} \frac{M}{\rho} \hat{m} \bullet \nabla_{P} U=-\frac{C_{m}}{\gamma} \frac{M}{\rho} g_{m}
$$

dimana $\rho$ adalah densitas batuan, $M$ adalah intensitas magnetisasi, $\hat{m}$ adalah vektor satuan magnetisasi, dan $g_{m}$ adalah komponen medan gravitasi dalam arah magnetisasi.

\section{Bahan dan Metode}

Penelitian ini telah dilaksanakan di wilayah Desa Cipari, Kecamatan Cipari, Kabupaten Cilacap Jawa Tengah. Penelitian ini dilaksanakan selama delapan bulan yaitu bulan Maret hingga Oktober 2015. Tahapan kegiatan yang dilakukan meliputi akuisisi data di lapangan, pengolahan, pemodelan dan

101 | Copyright (C) 2016, Wahana Fisika 
interpretasi. Peralatan yang digunakan dalam penelitian adalah Proton Precession Magnetometers GSM-19T produk GEM System dengan sensitivitas $0,05 \mathrm{nT}$ yang ditunjang oleh peralatan-peralatan lain seperti Global Positioning System (GPS), peta geologi, kompas, dan sebagainya.

Data yang terukur di lapangan adalah intensitas medan magnetik total dilengkapi posisi geografis titik-titik survei. Koreksi terhadap data-data magnetik total yang meliputi koreksi harian dan koreksi IGRF dilakukan, sehingga diperoleh data anomali magnetik total. Data anomali magnetik total yang masih terdistribusi di atas topografi, kemudian ditransformasikan ke bidang datar dan dibersihkan dari efek magnetik regional, sehingga diperoleh data anomali magnetik lokal atau residual. Berdasarkan data anomali magnetik lokal, selanjutnya dilakukan transformasi pseudogravitasi dan dilanjutkan pemodelan menggunakan software Mag2DC for Window untuk menggambarkan model struktur geologi atau batuan bawah permukaan [4].

\section{Hasil dan Pembahasan}

Jumlah data medan magnetik total yang terukur adalah 283 buah yang membentang pada posisi $108,75675^{\circ}-108,77611^{\circ} \mathrm{BT}$ dan $7,42319^{\circ}-7,43761^{\circ} \mathrm{LS}$ dengan nilai $43.724,57 \mathrm{nT}$ - 45.789,43nT. Data medan magnetik total hasil akuisisi di lapangan masih mengandung data medan magnetik utama bumi dan data medan magnetik luar. Untuk memperoleh data anomali magnetik total yang menjadi target penelitian maka dilakukan koreksi yang meliputi koreksi IGRF (International Geomagnetic Reference Field) untuk mereduksi data medan magnetik utama bumi dan koreksi harian untuk mereduksi data medan magnetik luar [5]. Data anomali magnetik total yang diperoleh setelah dilakukan koreksi-koreksi tersebut berkisar -187,16nT - 636,18nT dengan peta kontur seperti terlihat pada Gambar 1. 


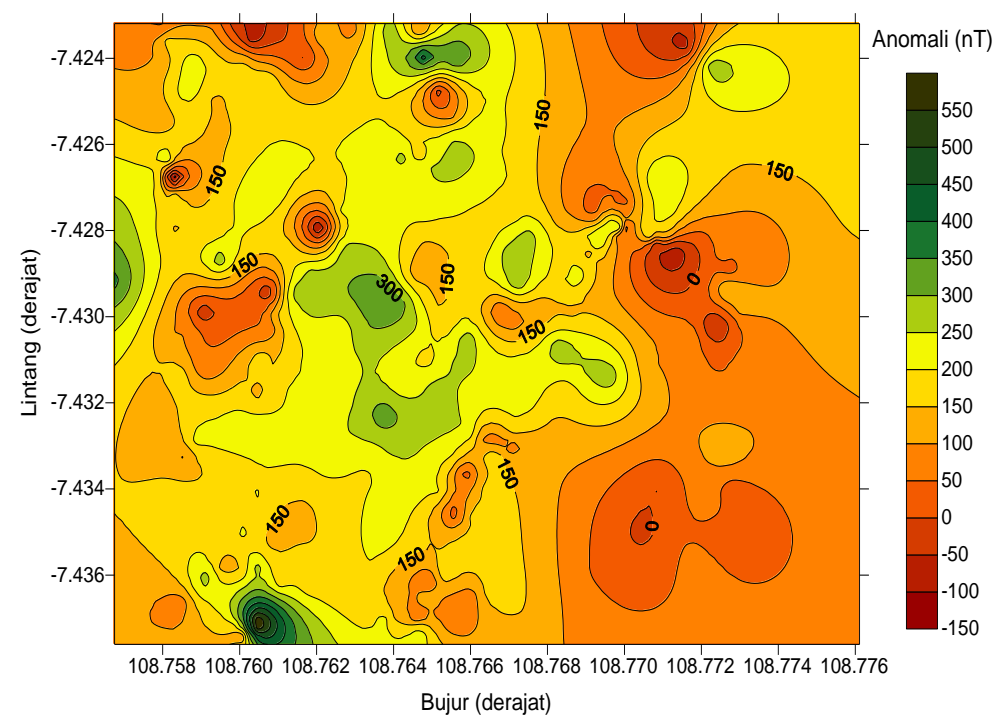

Gambar 1. Peta kontur anomali medan magnetik total daerah penelitian; Desa Cipari, Kecamatan Cipari, Kabupaten Cilacap.

Berdasarkan Gambar 1 trend anomali atas sferoida referensi, relatif lebih magnetik di daerah penelitian didominasi konvergen dengan nilai anomali magnetik anomali tinggi. Data anomali magnetik total berkisar $-68,30-603,14$ nT. yang diperoleh ini masih terdistribusi di atas permukaan topografi. Secara matematis data tersebut tidak dapat diproses pada tahap berikutnya jika tidak terdistribusi pada bidang datar [6]. Metode yang dapat digunakan untuk mentransformasikan data anomali magnetik dari bidang tidak datar (misalnya topografi) ke bidang datar adalah melalui pendekatan deret Taylor [3]. Berdasarkan hasil transformasi ini diketahui bahwa data anomali magnetik yang telah terdistribusi pada bidang datar, yaitu pada ketinggian rata-rata topografi 95,32 meter di

Data anomali medan magnetik total yang telah terdistribusi di bidang datar masih belum bersih dari efek anomali regional. Oleh karena itu efek anomali regional harus direduksi [7], mengingat target penelitian adalah struktur batuan di dekat permukaan atau lokal. Anomali magnetik regional dapat diperoleh melalui proses pengangkatan ke atas (upward continuation) terhadap data anomali magnetik total hingga variasi datanya menunjukkan trend yang relatif tetap [8]. Selanjutnya data anomali regional dikoreksikan terhadap data anomali magnetik 
total yang terdistribusi pada bidang datar. anomali magnetik lokal atau residual dengan Data hasil koreksi itu disebut sebagai data peta kontur bisa dilihat pada Gambar 2.

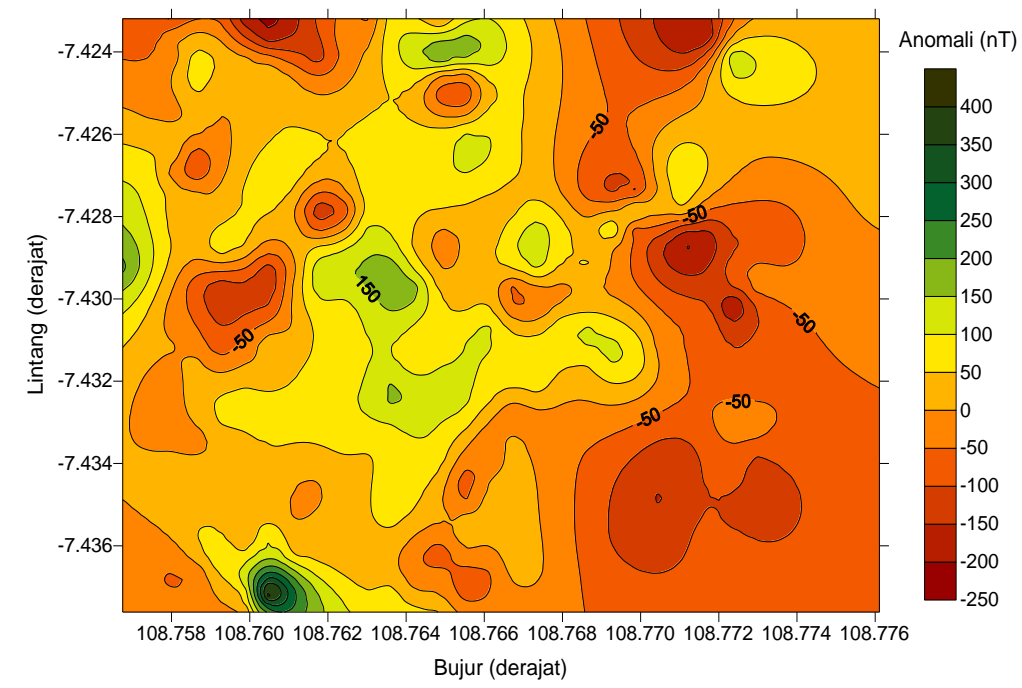

Gambar 2. Peta kontur anomali medan magnetik lokal (residual) daerah penelitian.

Peta kontur anomali magnetik lokal menunjukkan kerumitan closure anomali. Untuk memperjelas target anomali bawah permukaan maka dilakukan transformasi pseudogravitasi yaitu mentransformasi data anomali magnetik menjadi data anomali gravitasi semu. Metode ini merupakan cara untuk menginterpretasi anomali magnetik secara kualitatif. Hal tersebut bukan sematamata karena distribusi medan gravitasi secara aktual sesuai dengan distribusi magnetik, namun karena anomali gravitasi dalam beberapa hal lebih instruktif dan mudah diinterpretasi. Kontur anomali pseudogravitasi seperti Gambar 4 terlihat lebih sederhana dan informatif. Namun peta kontur tersebut hanya anomali gravitasi semu sehingga tidak dapat dimodelkan. Tetapi kontur pseudogravitasi dapat digunakan sebagai dasar dalam melakukan interpretasi kualitatif dan menentukan lokasi pemodelan anomali magnetik lokal, dengan tetap mengacu pada informasi geologi. Lokasi source rock rembesan minyak di daerah penelitian diinterpretasi berada dalam zona garis biru pada peta kontur pseudogravitasi, karena lapisan dasarnya diperkirakan berupa batuan beku yang memiliki densitas besar untuk memerangkap atau menampung rembesan minyak. 


\section{Wahana Fisika, 1(2), 2016}

http://ejournal.upi.edu/index.php/wafi

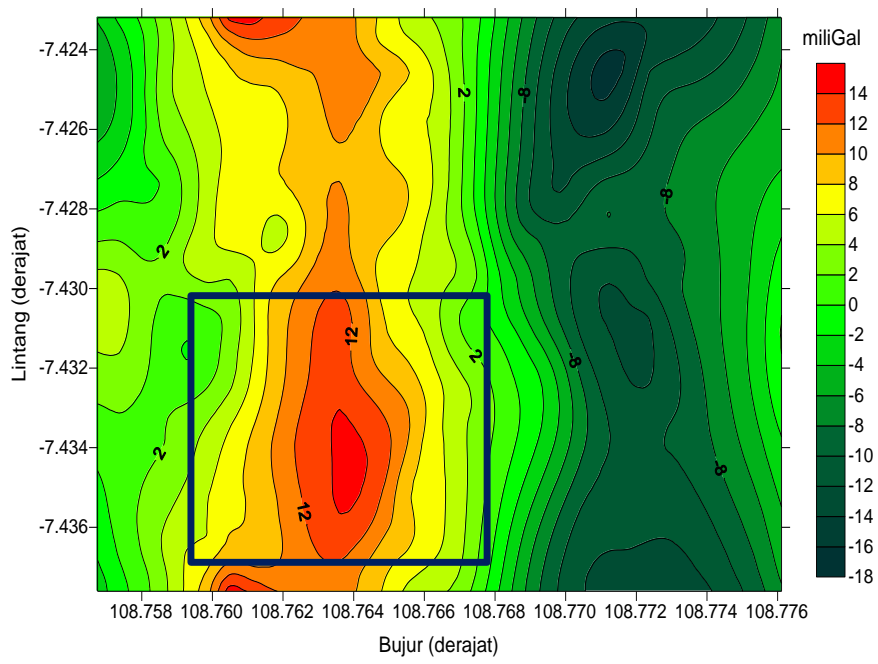

Gambar 4. Peta kontur anomali pseudogravitasi daerah penelitian(garis kotak biru diperkirakan sebagai lokasi source rock rembesan minyak)

Interpretasi dilakukan melalui informasi peta anomali pseudogravitasi. pemodelan numerik menggunakan Mag2DC Lintasan dibuat di atas peta kontur anomali for Windows. Langkah awal pemodelan ini magnetik lokal seperti Gambar 5. adalah membuat lintasan (line section) dari Pemodelan dilakukan terhadap data-data zona anomali positif menuju ke anomali anomali magnetik lokal yang diekstrak dari negatif atau sebaliknya yang diperkirakan lintasan tersebut menggunakan perangkat sebagai target anomali magnetik yakni lunak Surfer 10.

source rock rembesan minyak sesuai

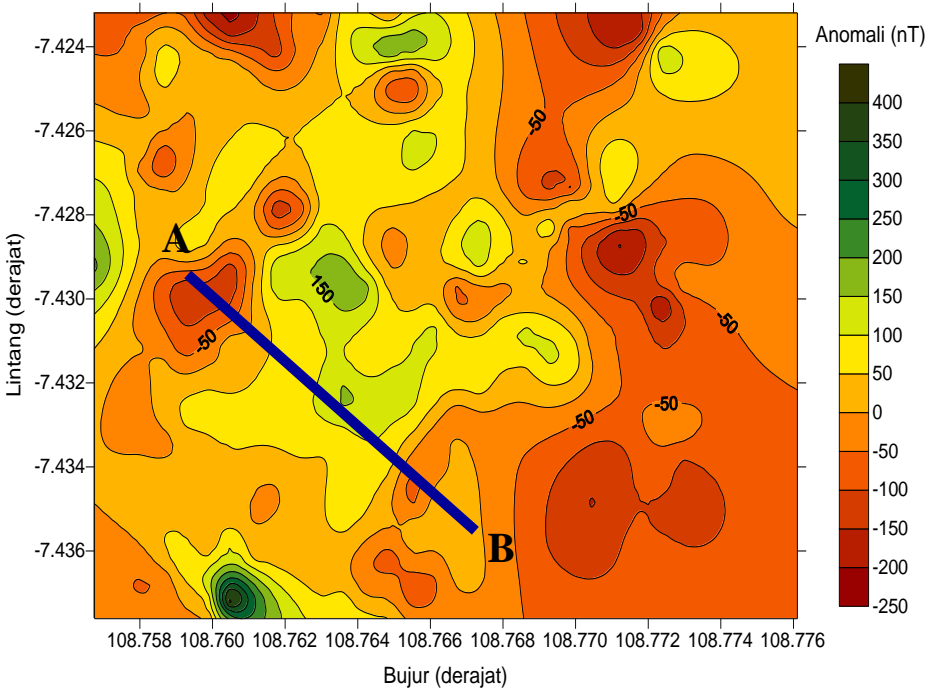


Gambar 5. Lintasan pemodelan di atas peta kontur anomali magnetik lokal daerah penelitian

Dalam melakukan pemodelan anomali $108,76731^{\circ} \mathrm{BT}$ dan $7,43662^{\circ} \mathrm{LS}$. Pemodelan magnetik diperlukan beberapa parameter medan magnetik bumi daerah penelitian yang meliputi nilai IGRF, sudut deklinasi, sudut inklinasi, dan beberapa parameter model lainnya. Parameter diunduh dari National Geophysical Data Center (NGDC) secara online, dengan hasil IGRF adalah 44963 nT, sudut deklinasi adalah $0,87^{\circ}$, dan sudut inklinasi adalah $-32,261^{\circ}$ [9]. Panjang strike diestimasi sebesar 100 meter dan kedalaman maksimum 750 meter. Pemodelan dilakukan pada lintasan $\mathrm{AB}$ yang panjangnya 1175,73 dilakukan menggunakan perangkat lunak Mag2DC for Windows dengan mencocokkan kurva anomali model terhadap kurva anomali observasi. Setelah dicapai kecocokan antara kedua kurva, maka diperoleh 9 (sembilan) benda anomali yang diasumsikan sebagai batuan bawah permukaan di daerah penelitian seperti Gambar 6. Berdasarkan informasi geologi, batuan lingkungan bawah permukaan di daerah penelitian diinterpretasi sebagai perselingan batupasir-batulempung $\mathrm{m}$ dan membentang dari posisi estimasi suseptibilitas magnetik rata-rata $108,75988^{\circ} \mathrm{BT}$ dan $7,42912^{\circ} \mathrm{LS}$ hingga sebesar 0,00250cgs unit [10].

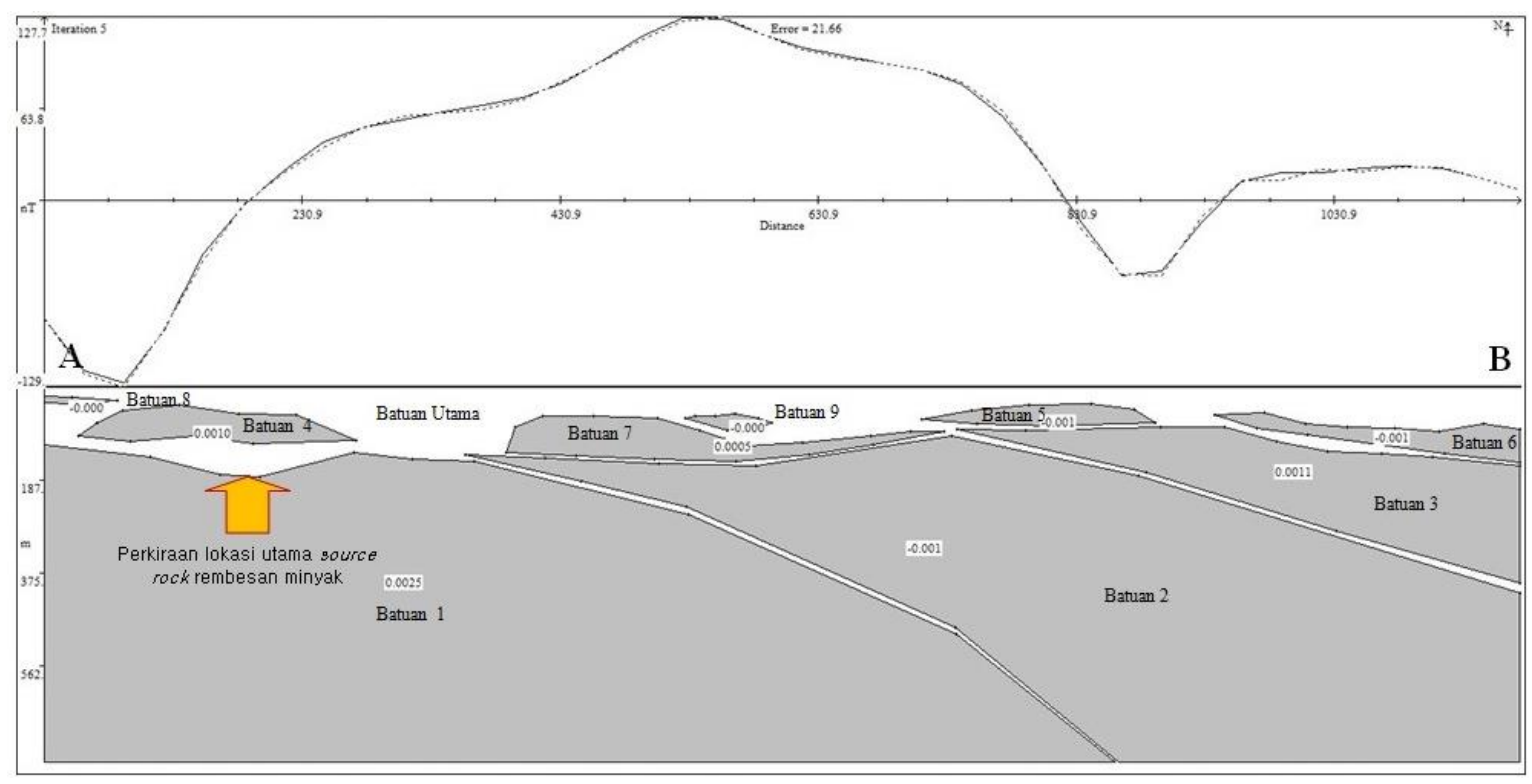

Gambar 6. Hasil pemodelan menggunakan software Mag2DC for Window terhadap data-data pada lintasan AB (panjang lintasan $\mathrm{AB}$ adalah 1175,73 meter dan error 21,66 nT) 
Sedangkan hasil interpretasi litologi, Proses migrasi minyak yang berasal dari kontras suseptibilitas magnetik $(\Delta \chi)$, dan batuan induk menuju batuan reservoir estimasi nilai suseptibilitas magnetik blok (source rock) diduga berasal dari selatan batuan $(\chi)$ ditunjukan pada Tabel 1. menuju ke utara. Migrasi minyak mengisi Berdasarkan informasi geologi rembesan struktur-struktur antiklin yang terbentuk minyak bumi diperkirakan terletak di bagian kemudian di kawasan utara dan terjebak pada utara antiklin yang berarah barat - timur. puncak-puncak antiklin tersebut [11].

Tabel 1. Interpretasi hasil pemodelan data-data anomali magnetik pada lintasan AB berdasarkan nilai suseptibilitas magnetik dalam satuan cgs

\begin{tabular}{|c|c|c|c|c|}
\hline $\begin{array}{c}\text { Batuan } \\
\text { ke }\end{array}$ & Kedalaman (meter) & $\begin{array}{c}\Delta \chi \\
\text { (cgs units) }\end{array}$ & $\begin{array}{l}\text { Estimasi } \chi \\
\text { (cgs units) }\end{array}$ & $\begin{array}{c}\text { Interpretasi } \\
\text { Formasi dan Jenis Batuan }\end{array}$ \\
\hline 1 & $(141,045-758,955)$ & 0,00260 & 0,00510 & Batuan beku basaltik \\
\hline 2 & $(98,507-758,955)$ & $-0,00110$ & 0,00140 & $\begin{array}{l}\text { Perselingan antara batupasir dan batulempung } \\
\text { dengan sisipan napal dari Formasi Halang }\end{array}$ \\
\hline 3 & $(35,821-114,179)$ & 0,00100 & 0,00350 & Batuan breksi basaltik dari Formasi Kumbang \\
\hline 4 & $(80,597-396,269)$ & 0,00110 & 0,00360 & $\begin{array}{l}\text { Perselingan batulempung-batupasir dengan } \\
\text { sisipan napal dan breksi (lebih kompak) dari } \\
\text { Formasi Halang }\end{array}$ \\
\hline 5 & $(33,582-78,35$ & $-0,00100$ & 0,00150 & Batulempung dari Formasi Tapak \\
\hline 6 & $(51,493-152,239)$ & $-0,00100$ & 0,00150 & Batulempung dari Formasi Tapak \\
\hline 7 & $(58,209-149,254)$ & 0,00050 & 0,00300 & $\begin{array}{l}\text { Perselingan batulempung-batupasir dengan } \\
\text { sisipan napal dan breksi dari Formasi Halang }\end{array}$ \\
\hline 8 & $(17,910-33,582)$ & $-0,00050$ & 0,00200 & $\begin{array}{l}\text { Perselingan batupasir-batulempung dari } \\
\text { Formasi Halang }\end{array}$ \\
\hline 9 & $(53,731-87,313)$ & $-0,00050$ & 0,00200 & $\begin{array}{l}\text { Perselingan batupasir-batulempung dari } \\
\text { Formasi Halang }\end{array}$ \\
\hline
\end{tabular}

Berdasarkan hasil pemodelan di atas source rock diinterpretasi sebagai perselingan antara batulempung dan batupasir dengan sisipan napal dan breksi (meliputi batuan 4, batuan 7, dan batuan lingkungan yang terletak di atas batuan 1). Sedangkan fosil foraminifer plantonik yang diperkirakan merupakan sumber minyak diperkirakan terdapat dalam batuan-batuan sedimen. Aliran minyak diinterpretasi mengarah relatif dari kanan (selatan) menuju ke kiri (utara) dan selanjutnya terkumpul di dalam batuan reservoir seperti terlihat pada Gambar 6. Berdasarkan hasil pemodelan tersebut, kedalaman source rock diperkirakan adalah 132,09 meter di bawah ketinggian rata-rata topografi dengan posisi $108,76164^{\circ} \mathrm{BT}$ dan $7,43089^{\circ} \mathrm{LS}$. Berdasarkan 
hasil analisis mikropaleontologi terhadap sampel-sampel batuan yang ditemukan di sekitar lokasi rembesan minyak diidentifikasi adanya fosil foraminifera plantonik [11].

\section{Simpulan}

Akuisisi data medan magnetik total di daerah Cipari Kabupaten Cilacap telah dilakukan di 283 titik lokasi yang 5. Ucapan Terima Kasih membentang pada posisi $108,75675^{\circ}-$ $108,77611^{\circ} \mathrm{BT}$ dan $7,42319^{\circ}-7,43761^{\circ} \mathrm{LS}$, dengan nilai $43.724,57$ - 45.789,43nT. Selanjutnya data tersebut dikoreksi dan direduksi sehingga diperoleh data anomali magnetik lokal yang bernilai -215,03 456,42 nT pada ketinggian rata-rata topografi yaitu 95,32 meter di atas sferoida referensi. Transformasi pseudogravitasi diterapkan pada data anomali magnetik lokal untuk memperjelas lokasi target anomali bawah permukaan, dan menghasilkan data anomali berkisar -16,73 - 15,20 miliGal. Berdasarkan peta kontur anomali pseudogravitasi yang didukung informasi geologi, dilakukan pemodelan terhadap data anomali magnetik lokal menggunakan perangkat lunak Mag2DC for Windows yang menghasilkan sembilan buah benda anomali. Berdasarkan hasil pemodelan, batuan reservoir (source rock) diinterpretasi merupakan perselingan antara batulempung dan batupasir dengan sisipan napal dan breksi. Lokasi source rock utama terletak pada posisi geografis $108,76164^{\circ} \mathrm{BT}$ dan $7,43089^{\circ} \mathrm{LS}$ dengan kedalaman 132,09 meter di bawah topografi rata-rata.

Terima kasih kami sampaikan kepada Rektor UNSOED dan Ketua Lembaga Penelitian dan Pengabdian Masyarakat (LPPM) UNSOED atas dana penelitian yang diberikan. Terima kasih disampaikan kepada Kepala Laboratorium Elektronika, Instrumentasi, dan Geofisika FMIPA UNSOED atas peralatan PPM dan GPS yang disediakan. Terima kasih juga disampaikan kepada seluruh tim yang terdiri atas dosen dan mahasiswa yang telah bekerja secara sinergis dan bahu-membahu melakukan akuisisi data medan magnetik total di Desa Cipari, Kecamatan Cipari, Kabupaten Cilacap.

\section{Referensi}

1. Sehah, Raharjo, S.A., Dewi, R. (2012). Pemanfaatan Data Seismisitas untuk Memetakan Tingkat Resiko 
Bencana Gempabumi di Kawasan

Eks-Karesidenan Banyumas Jawa

Tengah. Prosiding Seminar Nasional

Pengembangan Sumberdaya

Pedesaan dan Kearifan Lokal

Berkelanjutan II, 27 - 28 Nopember 2012. 7 - 15. Purwokerto.

2. Alamdar, K., Ansari, A.H., Ghorbani, A. (2009). Edge Detection of Magnetic Body Using Horizontal Gradient of Pseudogravity Anomaly. Geophysical Research, Vol. 11. EGU2009 - 4082.

3. Blakely R.J. (1995). Potential Theory in Gravity and Magnetic Applications. Cambridge University Press.

4. Nurdiyanto, B., Wahyudi, Suyanto, I. (2004). Analisis Data Magnetik untuk Mengetahui Struktur Bawah Permukaan Daerah Manifestasi Air Panas di Lereng Utara Gunungapi Ungaran. Prosiding Himpunan Ahli Geofisika Indonesia. Pertemuan Ilmiah Tahunan ke-29. 5 - 7 Oktober 2004. 36 - 45. Yogyakarta.

5. Syirojudin, M. (2010). Penentuan Karakteristik Sesar Cimandiri Segmen Pelabuhan Ratu Citarik dengan Metode Magnet Bumi. Skripsi-S1. Program Studi Fisika, Fakultas Sains dan Teknologi, Universitas Islam Negeri Syarif Hidayatullah. Jakarta.

6. Zulekho, S. (2015). Pendugaan Bawah Permukaan Situs Arkeologi Fosil Berdasarkan Data Magnetik di Sekitar Museum Manusia Purba Sangiran Sragen. Skripsi-S1. Program Studi Fisika, Fakultas MIPA, Universitas Negeri Semarang.

7. Sehah, Raharjo, S.A., Wibowo, O. (2014). Pendugaan Model Sumber Anomali Magnetik Bawah Permukaan di Area Pertambangan Emas Rakyat Desa Paningkaban, Kecamatan Gumelar, Kabupaten Banyumas. Jurnal Fisika Indonesia, XVIII (53): $38-42$.

8. Satiawan, S. (2009). Aplikasi Kontinuasi ke Atas dan Filter Panjang Gelombang untuk Pemisahan Anomali Regional - Residual pada Data Geomagnetik. Skripsi - S1. Program Studi Teknik Geofisika. Fakultas Teknik Pertambangan dan Perminyakan. ITB. Bandung.

9. National Geophysical Data Center, 109 | Copyright (C) 2016, Wahana Fisika 
(06 Juni 2015). Magnetic Field

Calculator. National Center for

Invironmental Center. Oceanic and

Atmospheric Administration

(NOAA). URL:

https://www.ngdc.noaa.gov/geomag-

web.

10. Simanjuntak, T.O., dan Surono. (1992). Peta Geologi Lembar Pangandaran, Jawa. Pusat Penelitian dan Pengembangan Geologi (P3G). Bandung.

11. Anonim, (05 Juni 2015). Geologi Cekungan Jawa; Blog Geografi Lingkungan. URL:

http://geoenviron.blogspot.com. 